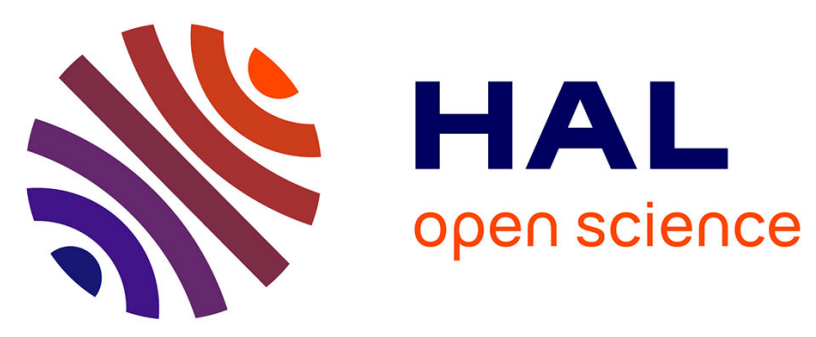

\title{
Ternary diagram: alpha-(3-benzoylphenyl)-propionic acid (ketoprofen) in acetone-water mixtures at different temperatures. Experimental data and predicted results
}

Fabienne Espitalier, Béatrice Biscans, P. Sere Peyrigain, C Laguérie

\section{- To cite this version:}

Fabienne Espitalier, Béatrice Biscans, P. Sere Peyrigain, C Laguérie. Ternary diagram: alpha(3-benzoylphenyl)-propionic acid (ketoprofen) in acetone-water mixtures at different temperatures. Experimental data and predicted results. Fluid Phase Equilibria, 1995, 113 (1-2), pp.151-171. 10.1016/0378-3812(95)02806-8 . hal-01868133

\section{HAL Id: hal-01868133 \\ https://hal.science/hal-01868133}

Submitted on 5 Sep 2018

HAL is a multi-disciplinary open access archive for the deposit and dissemination of scientific research documents, whether they are published or not. The documents may come from teaching and research institutions in France or abroad, or from public or private research centers.
L'archive ouverte pluridisciplinaire HAL, est destinée au dépôt et à la diffusion de documents scientifiques de niveau recherche, publiés ou non, émanant des établissements d'enseignement et de recherche français ou étrangers, des laboratoires publics ou privés. 


\title{
Ternary diagram: alpha-(3-benzoylphenyl)-propionic acid (ketoprofen) in acetone-water mixtures at different temperatures. Experimental data and predicted results
}

\author{
F. Espitalier ${ }^{a}$, B. Biscans ${ }^{a}$, P. Sere Peyrigain ${ }^{b}$, C. Laguérie ${ }^{\text {a }}$ \\ a Laboratoire de Génie chimique, URA CNRS 192, ENSIGC, 18 chemin de la Loge, 31078 Toulouse Cedex, France \\ ${ }^{\mathrm{b}}$ ProSim S.A., 18 chemin de la Loge, 31078 Toulouse Cedex, France
}

Received 16 September 1994; accepted 16 June 1995

\begin{abstract}
Experimental data are determined for a ternary system, ketoprofen-acetone-water, at various temperatures and atmospheric pressure. Specific procedures are applied. The diagram exhibits five regions: one homogeneous, three two-phase (two liquid-solid and one liquid-liquid equilibria) and one three-phase zones.

The variation of the solubility of ketoprofen in acetone-water mixtures is interpreted by analysing the molecular forces induced in the solution according to the acetone mass ratio in the mixture.

The validity of semi-empirical models is tested for liquid-solid and liquid-liquid equilibria by comparing the calculated values with the experimental ones. The agreement depends on the precision of the estimated parameters used for calculations.
\end{abstract}

Keywords: Multicomponent; Phase equilibria; Experimental data; Polar interactions; UNIQUAC model

\section{Introduction}

Liquid-solid equilibria (LSE) and liquid-liquid equilibria (LLE) data are needed in design of crystallization processes. For specific industrial problems, these data are rarely found in literature and must be most of time determined experimentally.

This study deals with a crystallization process in which a pharmaceutical drug, ketoprofen called "Ke" in this work, dissolved in acetone is precipitated out by adding water, acting as an anti solvent, to the solution. The aims of this article are to present experimental equilibria data for the system acetone-water-drug and to examine the validity of the semi-empirical models UNIQUAC for predictions of LLE and LSE, at several temperatures. 


\section{Experimental}

\subsection{Materials}

The pharmaceutical drug is a well-known antiinflammatory agent under generic name of ketoprofen. It is racemic $\alpha$-(3-benzoylphenyl)-propionic acid $( \pm)$. It is made up of three groups: a phenyl group $\left(-\mathrm{C}_{6} \mathrm{H}_{5}\right)$, a benzoyl group $\left(-\mathrm{C}_{6} \mathrm{H}_{4}-\mathrm{CO}\right)$ and an acetic chain $(-\mathrm{CH}-\mathrm{COOH})$. It is provided by Rhône-Poulenc Rorer Company.

Bidistilled water is used and synthesis grade acetone, with a minimum purity of $99.7 \%$, is purchased from Société de Distribution de Service et de Recherche.

\subsection{Procedure and techniques}

Preliminary experiments were carried out, with binary systems (ketoprofen-acetone on the one hand and ketoprofen-water on the other hand), and with the ternary system (ketoprofen-acetonewater), in order to roughly position the different zones of the ternary diagram. These preliminary experiments allowed to set up the experimental techniques. Then, more precise measurements were achieved.

The solubility of ketoprofen in acetone was determined according to an usual procedure (Mullin, 1972) consisting in dissolving periodically small amounts of ketoprofen in acetone contained in a 25 $\mathrm{ml}$ stirred vessel maintained at a constant temperature $\left(T \pm 0.1^{\circ} \mathrm{C}\right)$. When ketoprofen does not seem to dissolve any more, the suspension is still stirred for a few days more, during which the evolution of the concentration of ketoprofen in acetone is measured. The equilibrium is considered reached when the concentration remains constant. As the experiments proceed, loss of acetone due to evaporation is avoided by condensing the vapor. Sampling of the solution for the measurement of the concentration of ketoprofen in acetone requires stopping the stirring of the suspension for one hour and taking 1-3 $\mathrm{ml}$ from the solution with a syringe. The sample is then filtered through a $0.45 \mu \mathrm{m}$ porosity membrane and weighed at room temperature. The concentration of ketoprofen is obtained by weighing the dry solid after complete evaporation of the solvent.

The solubility of ketoprofen in water is determined according to the same experimental procedure as that described above. The concentrations of ketoprofen in water are measured by using a high performance liquid chromatograph (HPLC). The maximum relative deviation between all the data has been evaluated to $12 \%$ at $30^{\circ} \mathrm{C}$. This maximum can be explained by the difference between the solution temperature $\left(30{ }^{\circ} \mathrm{C}\right.$ ) and the room temperature (about 20-25 ${ }^{\circ} \mathrm{C}$ ) which can induce crystallization of the drug during sampling. However it can be noted that absolute deviations are only a few hundreds of ppm concentrations.

According to the number of the existing phases of the ternary system ketoprofen-acetone-water, three experimental procedures have been used. The first one is the dissolution procedure previously described for liquid-solid equilibria. The second one is a settling procedure for liquid-liquid equilibria. An acetone-water-ketoprofen mixture of about $100 \mathrm{ml}$, is stirred continuously for one hour in a reactor at a constant temperature controlled by less than $\pm 0.1^{\circ} \mathrm{C}$. After one hour agitation, this mixture is poured into a thermostated settling flask. After twenty four hours settling, the liquid aqueous and organic phases are separated and stored. The concentrations of ketoprofen and water are determined respectively by weighing the dry extract and by measuring out with a Karl Fisher titrator. 


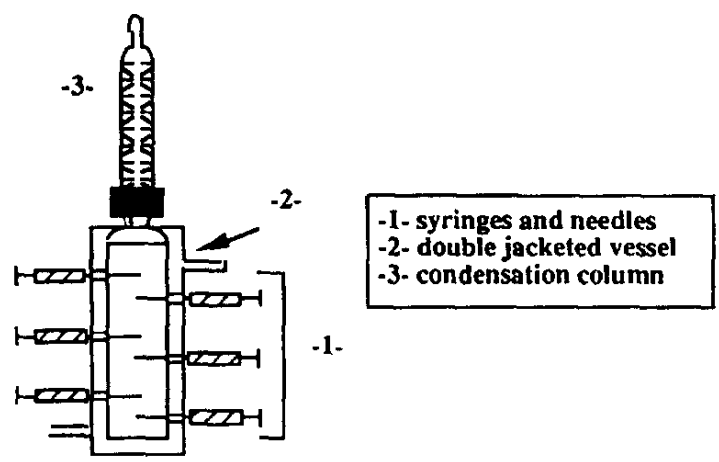

Fig. 1. Schematical representation of the reactor used to establish liquid-liquid-solid equilibrium.

The third procedure used is a specific procedure for liquid-liquid-solid equilibria. An acetonewater-ketoprofen mixture, of about $100 \mathrm{ml}$ is also continuously stirred for one hour in a particular reactor at constant temperature. The system is allowed to separate and settle in this reactor whose a schematic representation is shown in Fig. 1. The reactor is a small double jacketed glass vessel with facilities for sampling a few $\mathrm{ml}$ of the solution with syringes at various levels. So, syringes permit to take simultaneously samples of the two liquid phases without disturbing the equilibrium.

\section{Results}

The nature of the observed phases depends on the mass ratio of acetone in acetone-water mixtures $\left(R_{\mathrm{a}}\right)$.

For weight fractions of acetone in the acetone-water mixtures, $R_{\mathrm{a}}$, ranging approximately between 0 and 0.35 , and between 0.70 and 1 , a liquid-solid equilibrium is found. A liquid-liquid equilibrium is reached for values of $R_{\mathrm{a}}$ between 0.35 and 0.70 and a liquid-liquid-solid equilibria are obtained in the same range of $R_{\mathrm{a}}\left(0.35<R_{\mathrm{a}}<0.70\right)$.

\subsection{Binary systems}

Solubilities of ketoprofen in acetone and in pure water, at atmospheric pressure, are presented in Table 1 . The range of temperatures corresponds to that used in the crystallization process studied. The upper limit is fixed by the boiling point of acetone $\left(56^{\circ} \mathrm{C}\right)$. Deviations on the concentration of the

Table 1

Solubility of ketoprofen in pure acetone and in pure water solutions

\begin{tabular}{rll}
\hline Temperature $\left({ }^{\circ} \mathrm{C}\right)$ & $\begin{array}{l}\text { Solvent: acetone } W_{\mathrm{Ke}}^{*} \\
(\mathrm{~kg} \text { ketoprofen } / \mathrm{kg} \text { solution})\end{array}$ & $\begin{array}{l}\text { Solvent: water } W_{\mathrm{Ke}}^{*} \cdot 10^{6} \\
\text { (kg ketoprofen } / \mathrm{kg} \text { solution) }\end{array}$ \\
\hline 9.8 & $0.360 \pm 0.003$ & $86 \pm 3$ \\
19.8 & $0.431 \pm 0.007$ & $124 \pm 1$ \\
20.1 & & \\
29.9 & $0.513 \pm 0.005$ & $225 \pm 27$ \\
30.0 & & \\
41.1 & $0.613 \pm 0.005$ & \\
49.3 & $0.677 \pm 0.006$ & \\
\hline
\end{tabular}


Table 2

Solubility of ketoprofen in acetone-water mixture at $20.2{ }^{\circ} \mathrm{C}$

(a)

Experimental liquid-solid equilibrium at $20.15 \pm 0.15^{\circ} \mathrm{C}$

\begin{tabular}{|c|c|}
\hline $\begin{array}{l}\mathrm{W}_{\mathrm{Ke}}^{*} \\
\text { (kg ketoprofen / } \\
\mathrm{kg} \text { solution) }\end{array}$ & $\begin{array}{l}R_{\mathrm{a}} \\
(\mathrm{kg} \text { acetone } / \\
\mathrm{kg} \text { acetone- } \\
\text { water mixture) }\end{array}$ \\
\hline $151.5 \times 10^{-6} \pm 1.5 \times 10^{-6}$ & 0.016 \\
\hline $177 \times 10^{-6} \pm 8 \times 10^{-6}$ & 0.024 \\
\hline $337 \times 10^{-6} \pm 12 \times 10^{-6}$ & 0.072 \\
\hline $1410.5 \times 10^{-6} \pm 72 \times 10^{-6}$ & 0.163 \\
\hline 0.498 & 0.755 \\
\hline 0.517 & 0.786 \\
\hline 0.529 & 0.868 \\
\hline 0.502 & 0.910 \\
\hline 0.510 & 0.941 \\
\hline 0.487 & 0.961 \\
\hline
\end{tabular}

(b)

Experimental liquid-liquid-solid equilibrium at $20.0 \pm 0.1{ }^{\circ} \mathrm{C}$

\begin{tabular}{|c|c|c|c|c|}
\hline $\begin{array}{l}W_{\mathrm{Ke}}^{* \mathrm{aq}} \\
\text { (kg ketoprofen } / \\
\mathrm{kg} \text { solution) }\end{array}$ & $\begin{array}{l}R_{\mathrm{a}}^{\mathrm{aq}} \\
(\mathrm{kg} \text { acetone / } \\
\mathrm{kg} \text { acetone- } \\
\text { water mixture) }\end{array}$ & $\begin{array}{l}W_{\mathrm{Ke}}^{* \text { org }} \\
\text { (kg ketoprofen } / \\
\mathrm{kg} \text { solution) }\end{array}$ & $\begin{array}{l}R_{\mathrm{a}}^{\text {org }} \\
\text { (kg acetone / } \\
\mathrm{kg} \text { acetone- } \\
\text { water mixture) }\end{array}$ & \\
\hline 0.021 & 0.243 & 0.482 & 0.672 & \\
\hline \multicolumn{5}{|l|}{ (c) } \\
\hline$T\left({ }^{\circ} \mathrm{C}\right)$ & $\begin{array}{l}W_{\mathrm{Ke}}^{* \mathrm{aq}} \\
\text { (kg ketoprofen } / \\
\mathrm{kg} \text { solution) }\end{array}$ & $\begin{array}{l}R_{\mathrm{a}}^{\mathrm{aq}} \\
(\mathrm{kg} \text { acetone / } \\
\mathrm{kg} \text { acetone- } \\
\text { water mixture) }\end{array}$ & $\begin{array}{l}W_{\mathrm{Ke}}^{* \text { org }} \\
\text { (kg ketoprofen } / \\
\mathrm{kg} \text { solution) }\end{array}$ & $\begin{array}{l}R_{\mathrm{a}}^{\text {org }} \\
\text { (kg acetone/ } \\
\mathrm{kg} \text { acetone- } \\
\text { water mixture) }\end{array}$ \\
\hline 20.0 & $0.058 \pm 0.0004$ & 0.399 & $0.358 \pm 0.002$ & 0.649 \\
\hline 20.9 & $0.087 \pm 0.001$ & 0.438 & $0.305 \pm 0.004$ & 0.626 \\
\hline 20.7 & $0.098 \pm 0.001$ & 0.458 & $0.287 \pm 0.004$ & 0.600 \\
\hline 20.6 & $0.118 \pm 0.0003$ & 0.475 & $0.276 \pm 0.0008$ & 0.610 \\
\hline
\end{tabular}

solid in solution are also given in Table 1. The results show a high solubility of ketoprofen in acetone, and a very low solubility (a few hundreds of $\mathrm{ppm}$ ) of ketoprofen in pure water. In both cases, the solubilities obtained increase with increasing temperature.

\subsection{Ternary system}

Tables 2-5 report all the experimental data with their absolute deviation, in ternary mixtures at several temperatures $\left(10.1 \pm 0.1{ }^{\circ} \mathrm{C}, 20.2 \pm 0.2{ }^{\circ} \mathrm{C}, 30.2 \pm 0.2^{\circ} \mathrm{C}\right.$ and $\left.48.9 \pm 0.1{ }^{\circ} \mathrm{C}\right)$. 
Table 3

Solubility of ketoprofen in acetone-water mixture at $10.1{ }^{\circ} \mathrm{C}$

(a)

Experimental liquid-solid equilibrium at $10.15 \pm 0.15^{\circ} \mathrm{C}$

\begin{tabular}{ll}
$\begin{array}{l}\mathrm{W}_{\text {Ke }}^{*} \\
\text { (kg ketoprofen/ }\end{array}$ & $\begin{array}{l}R_{\mathrm{a}} \\
\text { (kg acetone/ } \\
\mathrm{kg} \text { solution) }\end{array}$ \\
$\begin{array}{l}\text { kg acetone- } \\
\text { water mixture) }\end{array}$ \\
\hline $105 \times 10^{-6} \pm 3 \times 10^{-6}$ & 0.023 \\
$199 \times 10^{-6} \pm 6 \times 10^{-6}$ & 0.072 \\
$623 \times 10^{-6} \pm 31 \times 10^{-6}$ & 0.151 \\
$2182 \times 10^{-6}$ & 0.219 \\
0.410 & 0.727 \\
0.427 & 0.773 \\
0.444 & 0.811 \\
0.447 & 0.888 \\
0.423 & 0.906 \\
0.447 & 0.960 \\
0.416 & 0.967 \\
\hline
\end{tabular}

(b)

Experimental liquid-liquid-solid equilibrium at $10.1 \pm 0.1{ }^{\circ} \mathrm{C}$

\begin{tabular}{|c|c|c|c|}
\hline $\begin{array}{l}\mathrm{W}_{\mathrm{Ke}}^{* \mathrm{aq}} \\
\text { (kg ketoprofen / } \\
\mathrm{kg} \text { solution) }\end{array}$ & $\begin{array}{l}R_{\mathrm{a}}^{\mathrm{aq}} \\
(\mathrm{kg} \text { acetone } / \\
\mathrm{kg} \text { acetone- } \\
\text { water mixture) }\end{array}$ & $\begin{array}{l}W_{\mathrm{Ke}}^{* \mathrm{org}} \\
\text { (kg ketoprofen / } \\
\mathrm{kg} \text { solution) }\end{array}$ & $\begin{array}{l}R_{\mathrm{a}}^{\text {org }} \\
(\mathrm{kg} \text { acetone / } \\
\mathrm{kg} \text { acetone- } \\
\text { water mixture) }\end{array}$ \\
\hline$\overline{0.073}$ & 0.462 & 0.269 & 0.606 \\
\hline
\end{tabular}

(c)

Binodal compositions of the experimental liquid-liquid equilibrium at $10.0 \pm 0.1{ }^{\circ} \mathrm{C}$

\begin{tabular}{llll}
\hline $\begin{array}{l}\mathrm{W}_{\mathrm{Ke}}^{* \mathrm{aq}} \\
\text { (kg ketoprofen/ } \\
\mathrm{kg} \text { solution) }\end{array}$ & $\begin{array}{l}R_{\mathrm{a}}^{\mathrm{aq}} \\
(\mathrm{kg} \text { acetone/ } \\
\text { kg acetone- } \\
\text { water mixture) }\end{array}$ & $\begin{array}{l}W_{\mathrm{Ke}}^{* \text { org }} \\
(\mathrm{kg} \text { ketoprofen/ } \\
\mathrm{kg} \text { solution) }\end{array}$ & $\begin{array}{l}R_{\mathrm{a}}^{\text {org }} \\
(\mathrm{kg} \text { acetone } / \\
\mathrm{kg} \text { acetone- } \\
\text { water mixture) }\end{array}$ \\
\hline $0.089 \pm 0.00001$ & 0.474 & $0.304 \pm 0.00006$ & 0.657 \\
\hline
\end{tabular}

Table 2 shows that the solubility of the drug at $20.2{ }^{\circ} \mathrm{C}$ slightly increases with the weight fraction of acetone for $R_{\mathrm{a}}<0.24$. The increase becomes more abrupt as $R_{\mathrm{a}}$ increases, up to a liquid-liquid phase splitting $\left(R_{\mathrm{a}}=0.24\right)$. The solubility reaches a maximum for a value of $R_{\mathrm{a}}$ in the interval contained between 0.90 and $0.95 \mathrm{~kg}$ acetone $\mathrm{kg}^{-1}$ acetone-water mixture. All these results are plotted in the ternary diagram illustrated in Fig. 2 at $20.2^{\circ} \mathrm{C}$. So, in acetone-water mixtures, depending on the acetone mass ratio, two phases (liquid-liquid or liquid-solid phases) are in equilibrium. These liquid-liquid and liquid-solid zones surround a three-phase area (liquid-liquid-solid). The different one-phase, two-phase and three-phase regions are indicated in Fig. 2 by the regions I, II, III.

The same trends have been observed for the other temperatures (Tables 3-5). The curves corresponding to $10.1,20.2,30.2$ and $48.9^{\circ} \mathrm{C}$ have been gathered on the same ternary diagram in Fig. 3. 
Table 4

Solubility of ketoprofen in acetone-water mixture at $30.2{ }^{\circ} \mathrm{C}$

(a)

Experimental liquid-solid equilibrium at $30.15 \pm 0.15^{\circ} \mathrm{C}$

\begin{tabular}{|c|c|}
\hline $\begin{array}{l}\mathrm{W}_{\mathrm{Ke}}^{*} \\
\text { (kg ketoprofen / } \\
\text { kg solution) }\end{array}$ & $\begin{array}{l}R_{\mathrm{a}} \\
\text { (kg acetone/ } \\
\mathrm{kg} \text { acetone- } \\
\text { water mixture) }\end{array}$ \\
\hline $261 \times 10^{-6} \pm 27 \times 10^{-6}$ & 0.017 \\
\hline $261 \times 10^{-6} \pm 17.10^{-6}$ & 0.026 \\
\hline 0.550 & 0.669 \\
\hline 0.577 & 0.730 \\
\hline 0.596 & 0.747 \\
\hline 0.589 & 0.796 \\
\hline 0.576 & 0.896 \\
\hline 0.602 & 0.902 \\
\hline 0.589 & 0.934 \\
\hline
\end{tabular}

(b)

Experimental liquid-liquid-solid equilibrium at $30.0 \pm 0.1{ }^{\circ} \mathrm{C}$

\begin{tabular}{llll}
\hline $\begin{array}{l}\mathrm{W}_{\mathrm{Kc}}^{* \text { aq }} \\
(\mathrm{kg} \text { ketoprofen/ }\end{array}$ & $\begin{array}{l}R_{\mathrm{a}}^{\mathrm{aq}} \\
(\mathrm{kg} \text { acetone } \\
\mathrm{kg} \text { solution) }\end{array}$ & $\begin{array}{l}W_{\mathrm{Ke}}^{\text {org }} \\
(\mathrm{kg} \text { ketoprofen/ } \\
\text { wacetone- } \\
\text { water mixture) }\end{array}$ & $\begin{array}{l}R_{\mathrm{a}}^{\text {org }} \\
(\mathrm{kg} \text { acetone/ } \\
\mathrm{kg} \text { acetone- } \\
\text { water mixture) }\end{array}$ \\
\hline 0.038 & 0.342 & 0.452 & 0.646
\end{tabular}

(c)
Binodal compositions of the experimental liquid-liquid equilibrium at $30.4 \pm 0.1^{\circ} \mathrm{C}$

\begin{tabular}{|c|c|c|c|}
\hline $\begin{array}{l}W_{\mathrm{Ke}}^{\mathrm{aq}} \\
\text { (kg ketoprofen / } \\
\mathrm{kg} \text { solution) }\end{array}$ & $\begin{array}{l}R_{\mathrm{a}}^{\mathrm{aq}} \\
(\mathrm{kg} \text { acetone / } \\
\mathrm{kg} \text { acetone- } \\
\text { water mixture) }\end{array}$ & $\begin{array}{l}W_{\mathrm{Ke}}^{*}{ }^{\text {org }} \\
\text { (kg ketoprofen } / \\
\mathrm{kg} \text { solution) }\end{array}$ & $\begin{array}{l}R_{\mathrm{a}}^{\mathrm{org}} \\
\text { (kg acetone / } \\
\mathrm{kg} \text { acetone- } \\
\text { water mixture) }\end{array}$ \\
\hline $0.058 \pm 0.0007$ & 0.367 & $0.359 \pm 0.004$ & 0.624 \\
\hline
\end{tabular}

Table 5

Solubility of ketoprofen in acetone-water mixture at $48.9^{\circ} \mathrm{C}$ : experimental liquid-solid equilibrium

\begin{tabular}{ll}
\hline $\begin{array}{l}W_{\text {Ke }}^{*} \\
\text { (kg ketoprofen/ } \mathrm{kg} \text { solution) }\end{array}$ & $\begin{array}{l}R_{\mathrm{a}}(\mathrm{kg} \text { acetone/ } \\
\mathrm{kg} \text { acetone-water mixture })\end{array}$ \\
\hline 0.703 & 0.852 \\
0.710 & 0.924 \\
0.701 & 0.950 \\
0.695 & 0.967 \\
\hline
\end{tabular}




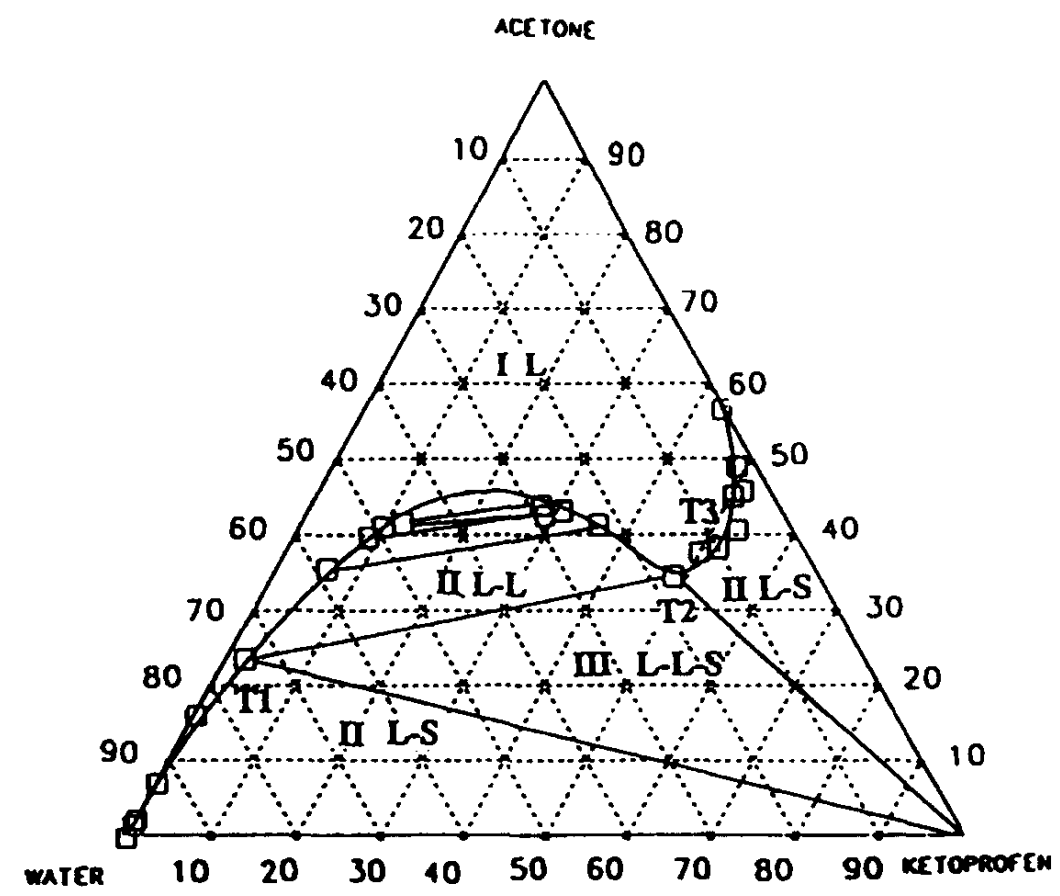

Fig. 2. Five different zones in the ternary diagram studied: one L area, two LSE area, one LLE area and one LLSE area. Experimental data at $20.2^{\circ} \mathrm{C}$.

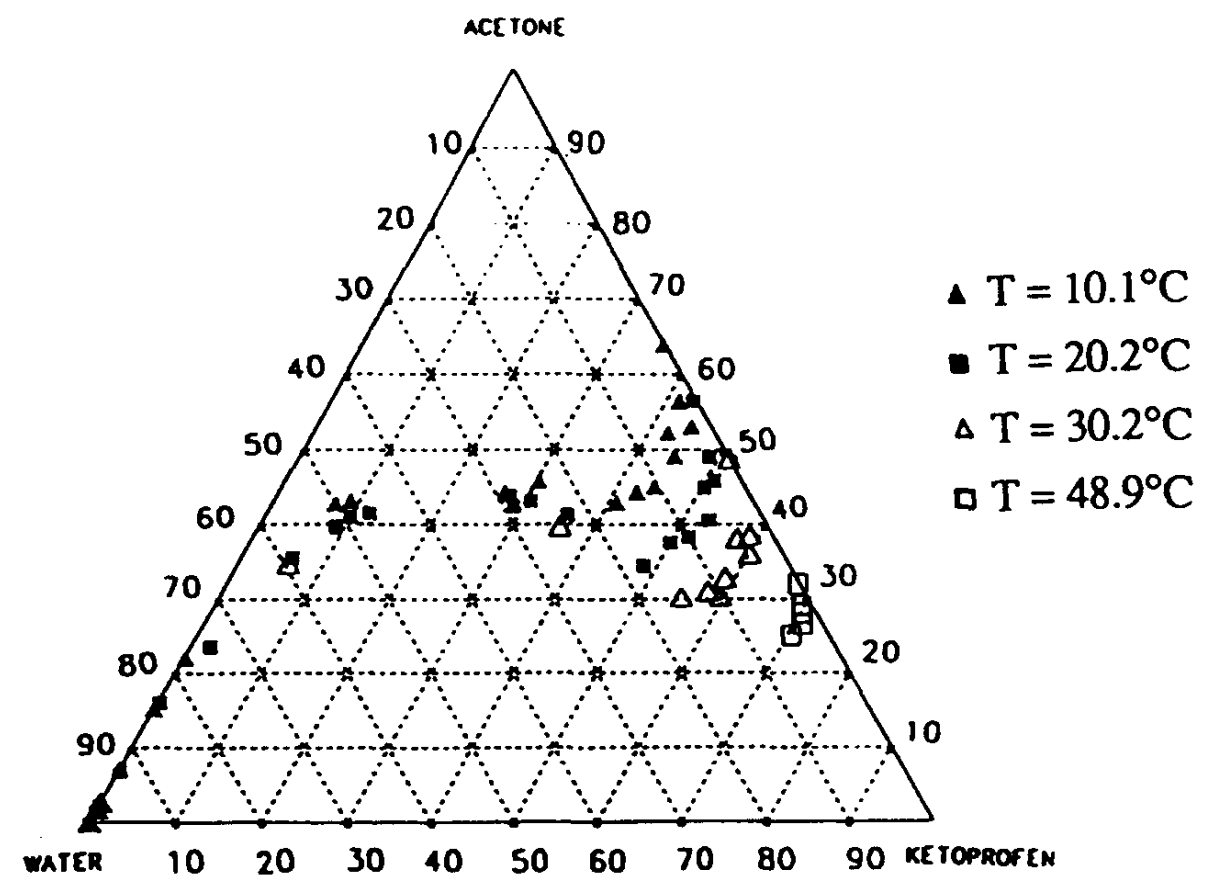

Fig. 3. Experimental data at $10.1,20.2,30.2$ and $48.9^{\circ} \mathrm{C}$. 
In the liquid-solid regions, the solubility of ketoprofen increases with temperature. However the influence of the temperature in these solid-liquid regions is much more important for high values of $R_{\mathrm{a}}$ on the right side of the phase diagram than for small ones on the left side.

A comparison between the liquid-liquid regions obtained respectively at $10.1{ }^{\circ} \mathrm{C}$ and $20.1{ }^{\circ} \mathrm{C}$ shows that this region is reduced as the temperature decreases. But this tendency is reversed when comparing the experimental points at $20.2{ }^{\circ} \mathrm{C}$ and $30.2{ }^{\circ} \mathrm{C}$. This last observation is probably due to the increase of experimental errors at $30.2^{\circ} \mathrm{C}$.

\section{Discussion}

Several observations can be drawn from the experimental data with binary and ternary systems.

First, let us deal with the difference of the solubility of ketoprofen according to the nature of the pure solvent used in the case of binary solutions.

The structure of the crystals has been modeled by using a molecular simulation software (Cavalier-Frontin et al., 1992). It has enabled us to build an elementary lattice of a crystal and a combination of elementary lattices. The atomic coordinates of ketoprofen crystal used have been given by Briard and Rossi (1990), from a crystallographic study. This representation shows that the crystal exhibits more numerous hydrophobic faces $\left(-\mathrm{C}_{6} \mathrm{H}_{5}\right)$ than hydrophilic ones $(-\mathrm{COOH})$. So water keeps its maximally hydrogen-bonded and voluminous structure in front of the hydrophobic faces and the drug is weakly soluble in water. On the contrary, acetone exhibits charges all along its

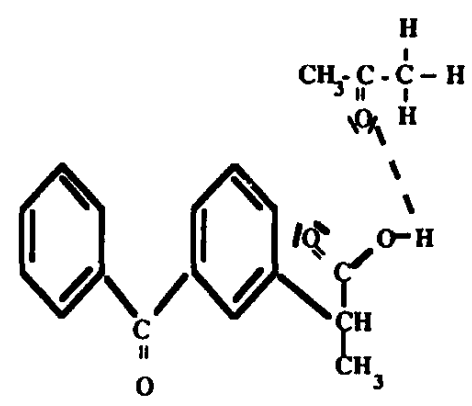

Fig. 4. Schematic representation of molecular interactions between the two components: ketoprofen-acetone.

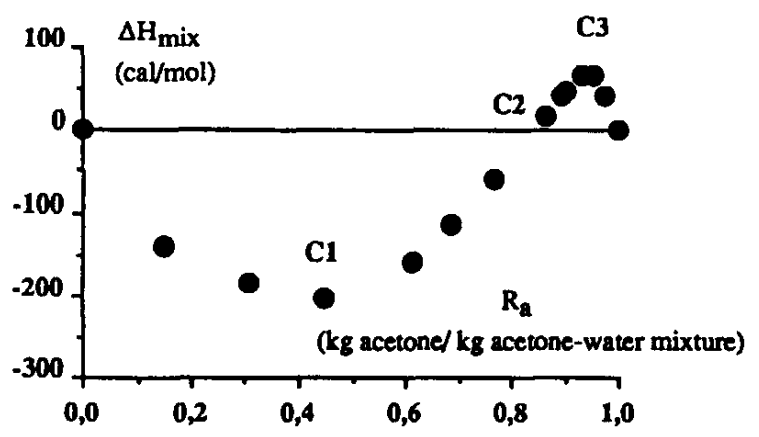

Fig. 5. Enthalpy of mixing data of acetone-water mixtures vs. acetone mass ratio, $R_{\mathrm{a}}$ at $20^{\circ} \mathrm{C}$ (Timmermans, 1960). 
structure so that hydrogen bonds are created with the ketoprofen molecules. Fig. 4 gives a schematic representation of the interactions occuring.

We have calculated the solubility of ketoprofen in acetone versus temperature, in the case of an ideal solution. The experimental solubility is $40 \%$ higher than the calculated one. This difference may be explained by the strong polar solvent-drug interactions which cannot be neglected when calculating activities of the components of the system (Bustamante and Selles, 1983).

In the case of the ternary system, it can also be referred to interactions between acetone and water. Mixtures of both species exhibit changes of structure with acetone mass ratio, $R_{\mathrm{a}}$. For example, these changes of structure affect the enthalpy of mixtures. Indeed, the study of the enthalpy of acetone-water mixture, $\Delta H_{\text {mix }}$, presents a particular behaviour versus acetone mass ratio as given in Fig. 5 (Timmermans, 1960). It shows that $\Delta H_{\text {mix }}$ is negative for $R_{\mathrm{a}} \leq 0.85$ and becomes positive for $R_{\mathrm{a}} \geq 0.85$. It can be assumed that the enthalpy of mixing, $\Delta H_{\mathrm{mix}}$, is the result of two additional thermal effects (Franks and Ives, 1966): the endothermic destruction of water-water hydrogen bonds and the exothermic formation of rather strong and well-organized acetone-water hydrogen bonds. It may be inferred that intercomponent attractions are dominant factors in the formation of acetone-water mixtures and in the formation of ketoprofen-acetone water mixtures.

Fig. 5 brings to the fore three particular points marked $\mathrm{C} 1, \mathrm{C} 2, \mathrm{C} 3$. Point $\mathrm{C} 2$ corresponds to $R_{\mathrm{a}}^{\mathrm{C2}}=0.85$ for which the enthalpy is equal to zero. Points $\mathrm{C} 1$ and $\mathrm{C} 3$ are respectively the minimum for $R_{\mathrm{a}}^{\mathrm{Cl}}=0.45$ and the maximum for $R_{\mathrm{a}}^{\mathrm{C3}}=0.92$ of the enthalpy curve. These particular ratios, $R_{\mathrm{a}}^{\mathrm{Cl}}$, $R_{\mathrm{a}}^{\mathrm{C} 2}, R_{\mathrm{a}}^{\mathrm{C} 3}$, can be compared to particular ratios, $R_{\mathrm{a}}^{\mathrm{T} 1}, R_{\mathrm{a}}^{\mathrm{T} 2}, R_{\mathrm{a}}^{\mathrm{T} 3}$, appearing in the ternary diagram of Fig. 2.

In the acetone-water mixture, for an acetone mass ratio less than $R_{\mathrm{a}}^{\mathrm{Cl}}$, the enthalpy of the mixture is negative and its absolute value increases as the acetone mass ratio increases: the number of hydrogen bonds between water molecules and acetone molecules increases. In the presence of ketoprofen, whose molecule has a ketone functional group in the acetic chain, the number of hydrogen bonds between water molecules, acetone molecules and ketoprofen molecules also increases. Thus, the solubility of ketoprofen in the mixture increases. In fact, the ternary diagram shows that the maximum solubility of ketoprofen is observed with an acetone mass ratio, $R_{\mathrm{a}}^{\mathrm{T1}}$, equal to approximately 0.24 .

For $R_{\mathrm{a}}$ between $R_{\mathrm{a}}^{\mathrm{Cl}}$ and $R_{\mathrm{a}}^{\mathrm{C} 2}$, i.e. between $\mathrm{C} 1$ and $\mathrm{C} 2$, the number of hydrogen bonds between water molecules and acetone molecules is important but decreases as the absolute value of $\Delta H_{\text {mix }}$ decreases. In fact, in the ternary system, two liquid phases are in equilibrium for $R_{\mathrm{a}}$ between 0.24 and 0.67 . Moreover liquid-liquid phase splitting occurs for $R_{\mathrm{a}}^{\mathrm{T} 1}=0.24$, at $20.0^{\circ} \mathrm{C}$.

For an acetone mass ratio equal to $R_{\mathrm{a}}^{\mathrm{C} 2}$ (point $\mathrm{C} 2$ in the Fig. 5), $\Delta H_{\text {mix }}$ is equal to zero. In the ternary mixture, the ratio corresponding to the change of two liquid phases in one liquid phase is 0.67 . It can be compared with the point where $\Delta H_{\text {mix }}$ is equal to zero.

As the acetone mass ratio increases between $R_{\mathrm{a}}^{\mathrm{C} 2}$ and $R_{\mathrm{a}}^{\mathrm{C} 3}$, the positive enthalpy of binary mixture increases: the number of hydrogen-bonded water molecules decreases; thus in the ternary mixture, the solubility of ketoprofen increases. On the ternary diagram the maximum solubility is obtained for $R_{\mathrm{a}}^{\mathrm{T} 3}$ equal to $0.90-0.95$.

For an acetone mass ratio above 0.92 , the number of hydrogen-bonded water molecules increases, and this increase explains the observed decrease of the solubility of ketoprofen in the ternary mixture.

The previous comparisons between the particular ratios appearing in the enthalpy diagram and those obtained in phase diagram, have shown the influence of ketoprofen. Indeed, the presence of 
ketoprofen in the mixture moves back the positions of the particular ratios obtained in the enthalpy diagram.

All this development has been made for a temperature of $20^{\circ} \mathrm{C}$. The behaviour of the ternary system at 10.1 or at $30.2{ }^{\circ} \mathrm{C}$ is similar to the one at $20.2{ }^{\circ} \mathrm{C}$ as shown in Fig. 3. But the particular ratios, $R_{\mathrm{a}}^{\mathrm{Tl}}, R_{\mathrm{a}}^{\mathrm{T2}}, R_{\mathrm{a}}^{\mathrm{T3}}$ are function of temperature.

\section{Representation model for LSE}

In the case of solute solid, the condition of equality of partial fugacities at equilibrium leads to the reduced relation (Walas, 1985):

$$
x_{\mathrm{S}}^{\mathrm{L}} \gamma_{\mathrm{S}}^{\mathrm{L}}=\exp \left(\frac{\Delta H_{\mathrm{m}}}{R}\left(\frac{1}{T_{\mathrm{m}}}-\frac{1}{T}\right)\right)
$$

with $x_{S}^{\mathrm{L}}$ : mol fraction of the solute, $\mathrm{S}$, in the solution

$\gamma_{\mathrm{S}}^{\mathrm{L}}$ : activity coefficient of the solute, $\mathrm{S}$, in the solution

$\Delta H_{\mathrm{m}}$ : melting enthalpy of the pure solid $\left(\mathrm{J} \mathrm{mol}^{-1}\right)$

$T_{\mathrm{m}}$ : melting temperature of the solid $(\mathrm{K})$

The required input data on ketoprofen are the melting enthalpy, $\Delta H_{\mathrm{m}}$, the melting temperature, $T_{\mathrm{m}}$, and the activity coefficient, $\gamma_{\mathrm{Ke}}^{\text {cal }}$.

$\Delta H_{\mathrm{m}}$ and $T_{\mathrm{m}}$ have been obtained for pure solid component by differential scanning calorimetry (DSC). They are respectively equal to $28,226 \pm 254 \mathrm{~J} \mathrm{~mol}^{-1}$ and $94.21 \pm 0.5^{\circ} \mathrm{C}$.

The LSE is calculated to find the optimal value of parameters by minimizing the difference between computed and experimental activity coefficients, $\gamma_{\mathrm{S}}^{\text {calc }}-\gamma_{\mathrm{S}}^{\text {exp }}$.

Using the same model for liquid phase activity coefficients, calculated either from measurements of vapor-liquid equilibria (VLE) or liquid-liquid equilibria (LLE), or liquid-solid equilibria (Walas, 1985), we have considered reasonable to choose the UNIQUAC model (Abrams and Prausnitz, 1975) to estimate $\gamma_{\mathrm{S}}^{\text {calc }}$ in the liquid phase.

The UNIQUAC model has a combinatorial contribution to the activity coefficients, essentially due to the differences in size and shape of the molecules, and a residual contribution essentially due to energetic interactions:

$$
\ln \gamma_{\mathrm{i}}=\ln \gamma_{\mathrm{i}}^{\mathrm{C}}+\ln \gamma_{\mathrm{i}}^{\mathrm{R}}
$$

The combinatorial term can be written as follows:

$$
\ln \gamma_{\mathrm{i}}^{\mathrm{C}}=\ln \frac{\phi_{\mathrm{i}}}{x_{\mathrm{i}}}+\frac{z}{2} * q_{\mathrm{i}} * \ln \frac{\theta_{\mathrm{i}}}{\phi_{\mathrm{i}}}+l_{\mathrm{i}}-\frac{\phi_{\mathrm{i}}}{x_{\mathrm{i}}} * \sum_{\mathrm{j}} x_{\mathrm{j}} l_{\mathrm{j}}
$$

where $z$ is the coordination number, equal to 10 ;

$$
l_{\mathrm{i}}=\frac{z}{2} *\left(r_{\mathrm{i}}-q_{\mathrm{i}}\right)-\left(r_{\mathrm{i}}-1\right)
$$


$\theta_{\mathrm{i}}$ and $\phi_{\mathrm{i}}$ are the molecular surface area and molecular volume of each component $\mathrm{i}$ with

$$
\begin{aligned}
& \phi_{\mathrm{i}}=\frac{r_{\mathrm{i}} x_{\mathrm{i}}}{\sum_{\mathrm{j}} x_{\mathrm{j}} r_{\mathrm{j}}} \\
& \theta_{\mathrm{i}}=\frac{q_{\mathrm{i}} x_{\mathrm{i}}}{\sum_{\mathrm{j}} x_{\mathrm{j}} q_{\mathrm{j}}}
\end{aligned}
$$

$x_{\mathrm{i}}$ is the mol fraction of the component $\mathrm{i}$.

Pure components parameters $r_{\mathrm{i}}$ and $q_{\mathrm{i}}$ are, respectively, determined from measurements of molecular van der Waals volumes and molecular surface areas. They are calculated as the sum of the group-volume and group-area parameters, $R_{\mathrm{k}}$ and $Q_{\mathrm{k}}$ :

$$
r_{\mathrm{i}}=\sum \nu_{\mathrm{k}}^{(\mathrm{i})} R_{\mathrm{k}} \text { and } q_{\mathrm{i}}=\sum \nu_{\mathrm{k}}^{(\mathrm{i})} Q_{\mathrm{k}}
$$

where $\nu_{k}^{(i)}$, always an integer, is the number of groups of type $k$ in the molecule i. Group parameters $R_{\mathrm{k}}$ and $Q_{\mathrm{k}}$ are obtained from van der Waals group volumes $V_{\mathrm{k}}$ and surface areas $A_{\mathrm{k}}$ (Bondi, 1964). The expression of $R_{\mathrm{k}}$ and $Q_{\mathrm{k}}$ can be given as follows:

$$
\begin{aligned}
R_{\mathrm{k}} & =\frac{V_{\mathrm{k}}}{15.17} \\
Q_{\mathrm{k}} & =\frac{A_{\mathrm{k}}}{2.5 * 10^{9}}
\end{aligned}
$$

The normalization factors appearing in Eqs. (8) and (9), 15.17 and $2.5 * 10^{9}$ are those derived by Abrams and Prausnitz (1975).

However, since data for the benzoyl group are not available, this group has been decomposed into two independent groups, $\mathrm{C}_{6} \mathrm{H}_{4}$ and $\mathrm{C}=\mathrm{O}$. The van der Waals group volumes, $V_{\mathrm{k}}$, and surface areas, $A_{\mathrm{k}}$ of $>\mathrm{C}=\mathrm{O}$ group are given by Bondi (1964). The other volume and surface factors of others groups have been found in Walas (1985).

The expression of the residual term, in UNIQUAC equation, is:

$$
\ln \gamma_{\mathrm{i}}^{\mathrm{R}}=q_{\mathrm{i}} *\left(1-\ln \left(\sum_{\mathrm{j}} \theta_{\mathrm{j}} \tau_{\mathrm{ji}}\right)-\sum_{j} \frac{\theta_{\mathrm{j}} \tau_{\mathrm{ij}}}{\theta_{\mathrm{k}} \tau_{\mathrm{kj}}}\right)
$$

with

$$
\tau_{\mathrm{ij}}=\exp \left(-\frac{u_{\mathrm{ij}}-u_{\mathrm{ii}}}{R T}\right)
$$

Table 6

Volume and surface factors, $r_{\mathrm{i}}$ and $q_{\mathrm{i}}$, calculated from data given by Walas, 1985

\begin{tabular}{lll}
\hline System & Volume factor & Surface factor \\
\hline Ketoprofen & 9.2979 & 6.900 \\
Acetone & 2.5735 & 2.336 \\
Water & 0.9200 & 1.400 \\
\hline
\end{tabular}


Table 7

Parameters of the UNIQUAC model for the system studied, LSE

\begin{tabular}{llc}
\hline System & $\mathrm{i}-\mathrm{i}$ & $u_{\mathrm{ij}}\left(\mathrm{J} \mathrm{mol}^{-1}\right)$ \\
\hline Ketoprofen(1)- & $1-2$ & -746.25 \\
Acetone(2) & $2-1$ & 747.13 \\
Ketoprofen(1)- & $1-3$ & 2931.03 \\
Water(3) & $3-1$ & -103.68 \\
Acetone(2)-water(3) & $2-3$ & 3744.90 \\
& $3-2$ & -866.76 \\
\hline
\end{tabular}

The $u_{\mathrm{ij}}$ are the interaction parameters between the two components $\mathrm{i}$ and $\mathrm{j}$. They can be found in tables.

These factors, $r_{\mathrm{i}}$ and $q_{\mathrm{i}}$, are reported in Table 6. The calculated values of ketoprofen volume and surface factors are high compared with the values obtained for the other components.

\section{Representation of the ternary system}

The validity of the semi-empirical models which represent LLE and LSE have been tested.

The parameters, $u_{\mathrm{ij}}$ and $u_{\mathrm{ji}}$ of the tested semi-empirical UNIQUAC model are not available in tables and have been evaluated for each particular binary system. The parameters of the system acetone-water are deduced from VLE data using the PROREG regression tool designed by PROSIM

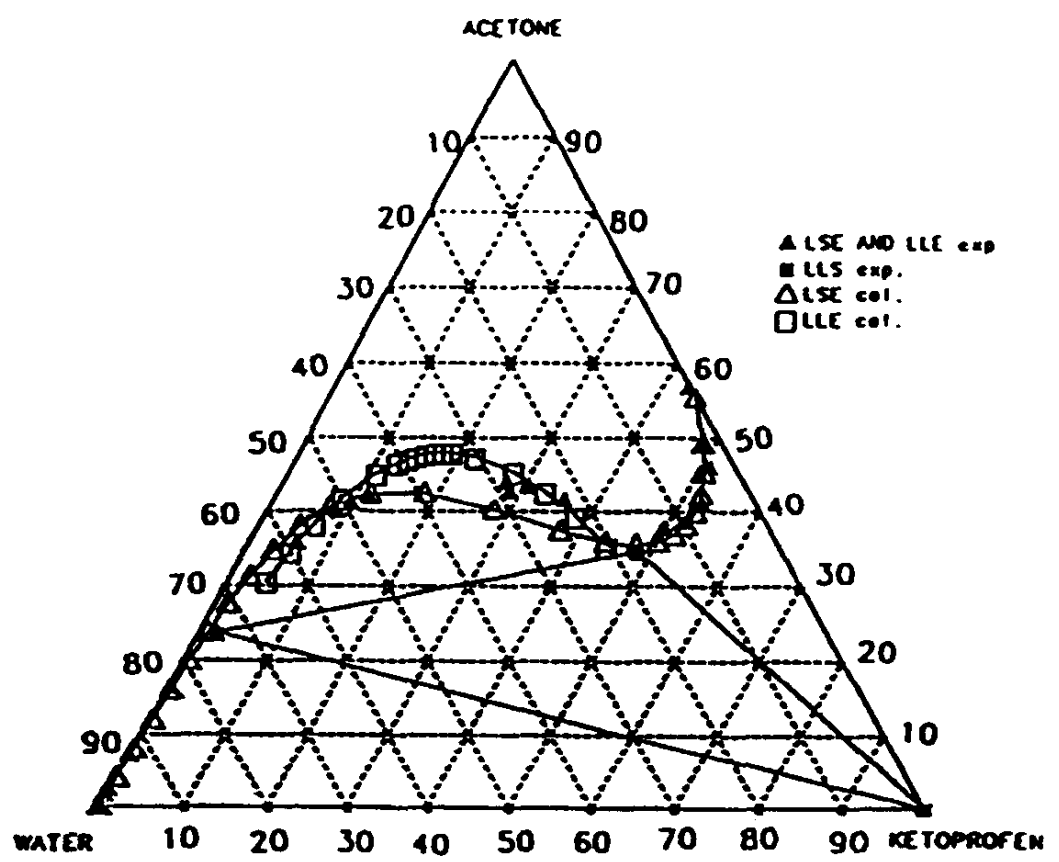

Fig. 6. Predicted LLE and LSE data (after adjustment of the interaction parameters between ketoprofen and water) and experimental data at $20.2^{\circ} \mathrm{C}$. 
Table 8

Relative deviations between the calculated and the experimental concentrations of ketoprofen $\left(\frac{\left(W_{\mathrm{Ke}}^{\mathrm{cal}}-W_{\mathrm{Ke}}^{\exp }\right)}{W_{\mathrm{Ke}}^{\exp }}\right)$ as a function of $R_{\mathrm{a}}$ at $10.1{ }^{\circ} \mathrm{C}$

\begin{tabular}{lll}
\hline $\begin{array}{l}R_{\mathrm{a}}(\mathrm{kg} \text { acetone/ } \\
\mathrm{kg} \text { acetone-water })\end{array}$ & $\begin{array}{l}\text { Absolute deviations } \\
\text { (kg ketoprofen/kg solution) }\end{array}$ & $\begin{array}{l}\text { Relative deviations } \\
\text { on concentration }(\%)\end{array}$ \\
\hline 0 & $2 \times 10^{-6}$ & 2 \\
0.023 & $1 \times 10^{-6}$ & 1 \\
0.072 & $37 \times 10^{-6}$ & 19 \\
0.151 & $291 \times 10^{-6}$ & 47 \\
0.219 & $1563 \times 10^{-6}$ & 72 \\
0.727 & 0.327 & 80 \\
0.775 & 0.292 & 68 \\
0.811 & 0.257 & 58 \\
0.888 & 0.147 & 33 \\
0.906 & 0.102 & 24 \\
0.960 & 0.088 & 20 \\
0.967 & 0.055 & 13 \\
1 & 0.001 & 0.2 \\
\hline
\end{tabular}

Company (ProSim S.A., 1993). For the systems, ketoprofen-acetone and ketoprofen-water, these parameters were computed from the experimental mutual solubility data, by minimization of the

$$
\text { differences } \frac{\left(\gamma_{\mathrm{Ke}}^{\text {calc }}-\gamma_{\mathrm{Ke}}^{\exp }\right)}{\gamma_{\mathrm{Ke}}^{\exp }} \text { and } \frac{\left(\gamma_{\text {solvent }}^{\text {calc }}-\gamma_{\text {solvent }}^{\text {exp }}\right)}{\gamma_{\text {solvent }}^{\text {exp }}}
$$

The parameters, $\mathrm{a}_{\mathrm{ij}}$ and $\mathrm{a}_{\mathrm{ji}}$, obtained are given in Table 7 .

Table 9

Relative deviations between the calculated and the experimental concentrations of ketoprofen $\left(\frac{\left(W_{\mathrm{Ke}}^{\mathrm{cal}}-W_{\mathrm{Ke}}^{\mathrm{exp}}\right)}{W_{\mathrm{Ke}}^{\mathrm{exp}}}\right)$ as a function of $R_{\mathrm{a}}$ at $20.2^{\circ} \mathrm{C}$

\begin{tabular}{|c|c|c|}
\hline $\begin{array}{l}R_{\mathrm{a}}(\mathrm{kg} \text { acetone } / \\
\mathrm{kg} \text { acetone-water })\end{array}$ & $\begin{array}{l}\text { Absolute deviations } \\
\text { (kg ketoprofen } / \mathrm{kg} \text { solution) }\end{array}$ & $\begin{array}{l}\text { Relative deviations } \\
\text { on concentration (\%) }\end{array}$ \\
\hline$\overline{0}$ & $13 \times 10^{-6}$ & 11 \\
\hline 0.016 & $7 \times 10^{-6}$ & 5 \\
\hline 0.024 & $6 \times 10^{-6}$ & 3 \\
\hline 0.072 & $73 \times 10^{-6}$ & 22 \\
\hline 0.163 & $804 \times 10^{-6}$ & 57 \\
\hline 0.755 & 0.303 & 61 \\
\hline 0.786 & 0.261 & 50 \\
\hline 0.868 & 0.136 & 26 \\
\hline 0.910 & 0.072 & 14 \\
\hline 0.941 & 0.064 & 13 \\
\hline 0.961 & 0.036 & 7 \\
\hline 1 & 0.015 & 4 \\
\hline
\end{tabular}


Table 10

Relative deviations between the calculated and the experimental concentrations of ketoprofen $\left(\frac{\left(W_{\mathrm{Ke}}^{\text {cal }}-W_{\mathrm{Ke}}^{\text {exp }}\right)}{W_{\mathrm{Ke}}^{\exp }}\right)$ as a function of $R_{\mathrm{a}}$ at $30.2^{\circ} \mathrm{C}$

\begin{tabular}{lll}
\hline$R_{\mathrm{a}}$ (kg acetone/ & $\begin{array}{l}\text { Absolute deviations } \\
\text { kg acetone-water) }\end{array}$ & $\begin{array}{l}\text { Relative deviations } \\
\text { on concentration }(\%)\end{array}$ \\
\hline 0 & $8 \times 10^{-6}$ & 3 \\
0.017 & $8 \times 10^{-6}$ & 3 \\
0.026 & $14 \times 10^{-6}$ & 5 \\
0.669 & 0.408 & 74 \\
0.730 & 0.295 & 51 \\
0.747 & 0.268 & 45 \\
0.796 & 0.156 & 27 \\
0.896 & 0.046 & 8 \\
0.902 & 0.070 & 12 \\
0.934 & 0.048 & 8 \\
1 & 0.019 & 4 \\
\hline
\end{tabular}

The calculated and experimental solubilities in the binary liquid-solid zones are shown at $20.2{ }^{\circ} \mathrm{C}$ in Fig. 6. It is important to note that the form of the calculated curve is very similar to the experimental one. Moreover this curve seems able to describe all regions, even the liquid-liquid region. This continuity can be explained by that of the thermodynamic equations used.

However, when comparing with experimental data, the UNIQUAC model gives underestimated concentrations of ketoprofen when the mass ratio of acetone is higher than 0.75 . The relative deviations between the calculated and the experimental concentrations of solute $\left(\left(\frac{W_{K e}^{c a l}-W_{K e}^{\text {exp }}}{W_{K e}^{\text {exp }}}\right) * 100\right)$ as a function of $R_{\mathrm{a}}$ are reported in Tables 8-11, for the different temperatures. For acetone-water mixtures with a high mass ratio of acetone, the deviation increases as $R_{\mathrm{a}}$ decreases. So the concentrations of ketoprofen are underestimated (until $80 \%$ at $10.1{ }^{\circ} \mathrm{C}$ ). For acetone-water mixtures with $R_{\mathrm{a}}$ less than 0.075 , there is a good agreement between experimental and

Table 11

Relative deviations between the calculated and the experimental concentrations of ketoprofen $\left(\frac{\left(W_{\mathrm{Ke}}^{\text {cal }}-W_{\mathrm{Ke}}^{\exp }\right)}{W_{\mathrm{Ke}}^{\exp }}\right)$ as a function of $R_{\mathrm{a}}$ at $48.9^{\circ} \mathrm{C}$

\begin{tabular}{|c|c|c|}
\hline $\begin{array}{l}R_{\mathrm{a}}(\mathrm{kg} \text { acetone / } \\
\mathrm{kg} \text { acetone water) }\end{array}$ & $\begin{array}{l}\text { Absolute deviations } \\
\text { ( } \mathrm{kg} \text { ketoprofen } / \mathrm{kg} \text { solution) }\end{array}$ & $\begin{array}{l}\text { Relative deviations } \\
\text { on concentration (\%) }\end{array}$ \\
\hline 0.852 & 0.007 & 1.0 \\
\hline 0.924 & 0.002 & 0.2 \\
\hline 0.950 & 0.003 & 0.4 \\
\hline 0.967 & 0.005 & 1 \\
\hline 1 & 0.011 & 2 \\
\hline
\end{tabular}


Table 12

Relative deviations between the calculated and the experimental concentrations of ketoprofen as a function of $R_{\mathrm{a}}$ at $10.1{ }^{\circ} \mathrm{C}$ (after adjustment of the interaction parameters between ketoprofen and water)

\begin{tabular}{llc}
\hline $\begin{array}{l}R_{\mathrm{a}}(\mathrm{kg} \text { acetone/ } \\
\mathrm{kg} \text { acetone-water })\end{array}$ & $\begin{array}{l}\text { Absolute deviations } \\
\text { (kg ketoprofen/kg solution) }\end{array}$ & $\begin{array}{l}\text { Relative deviations } \\
\text { on concentration }(\%)\end{array}$ \\
\hline 0 & $\mathrm{AAD}=2650 \times 10^{-6}$ & ARD $=820$ \\
0.023 & $1001 \times 10^{-6}$ & 1164 \\
0.072 & $1228 \times 10^{-6}$ & 1170 \\
0.151 & $1865 \times 10^{-6}$ & 937 \\
0.219 & $3566 \times 10^{-6}$ & 572 \\
& $5589 \times 10^{-6}$ & 256 \\
0.727 & $\mathrm{AAD}=0.013$ & ARD $=2.9$ \\
0.775 & 0.011 & 3 \\
0.811 & 0.015 & 3 \\
0.888 & 0.005 & 1 \\
0.906 & 0.002 & 0.3 \\
0.960 & 0.017 & 4 \\
0.967 & 0.037 & 8 \\
1 & 0.013 & 3 \\
\hline
\end{tabular}

calculated data (relative error is lower than $10 . \%$ ). However for $R_{\mathrm{a}}$ higher than 0.075 , the ketoprofen concentrations are underestimated too.

According to the principle of the method, the calculated concentrations directly depend on the estimated UNIQUAC parameters. An analysis of the values of these parameters can explain the reported error on the predicted values. In binary mixtures ketoprofen-water, with a low ketoprofen

Table 13

Relative deviations between the calculated and the experimental concentrations of ketoprofen as a function of $R_{\mathrm{a}}$ at $20.2{ }^{\circ} \mathrm{C}$ (after adjustment of the interaction parameters between ketoprofen and water)

\begin{tabular}{lll}
\hline $\begin{array}{l}R_{\mathrm{a}} \text { (kg acetone/ } \\
\mathrm{kg} \text { acetone water) }\end{array}$ & $\begin{array}{l}\text { Absolute deviations } \\
\text { (kg ketoprofen/kg solution) }\end{array}$ & $\begin{array}{l}\text { Relative deviations } \\
\text { on concentration }(\%)\end{array}$ \\
\hline 0 & AAD $=2197 \times 10^{-6}$ & ARD $=481$ \\
0.016 & $916 \times 10^{-6}$ & 738.5 \\
0.024 & $1048 \times 10^{-6}$ & 691.8 \\
0.072 & $1111 \times 10^{-6}$ & 628.0 \\
0.163 & $1644 \times 10^{-6}$ & 487.9 \\
& $3099 \times 10^{-6}$ & 219.8 \\
0.755 & $\mathrm{AAD}=0.009$ & ARD $=1.7$ \\
0.786 & 0.007 & 1.5 \\
0.868 & 0.003 & 0.5 \\
0.910 & 0.011 & 2.1 \\
0.941 & 0.007 & 1.5 \\
0.961 & 0.014 & 2.6 \\
1 & 0.003 & 0.6 \\
\hline
\end{tabular}


Table 14

Relative deviations between the calculated and the experimental concentrations of ketoprofen as a function of $R_{\mathrm{a}}$ at $30.2{ }^{\circ} \mathrm{C}$ (after adjustment of the interaction parameters between ketoprofen and water)

\begin{tabular}{lll}
\hline $\begin{array}{l}R_{\mathrm{a}}(\mathrm{kg} \text { acetone } \\
\mathrm{kg} \text { acetone water })\end{array}$ & $\begin{array}{l}\text { Absolute deviations } \\
(\mathrm{kg} \text { ketoprofen/kg solution) }\end{array}$ & $\begin{array}{l}\text { Relative deviations } \\
\text { on concentration }(\%)\end{array}$ \\
\hline 0 & $\mathrm{AAD}=904.3 \times 10^{-6}$ & ARD $=376$ \\
0.017 & $813 \times 10^{-6}$ & 361 \\
0.026 & $949 \times 10^{-6}$ & 363 \\
& $1051 \times 10^{-6}$ & 403 \\
0.669 & $\mathrm{AAD}=0.010$ & $\mathrm{ARD}=1.8$ \\
0.730 & 0.005 & 1 \\
0.747 & 0.001 & 0.2 \\
0.796 & 0.012 & 2 \\
0.896 & 0.004 & 1 \\
0.902 & 0.011 & 2 \\
0.934 & 0.017 & 3 \\
1.0 & 0.014 & 2 \\
\hline
\end{tabular}

content (hundreds of ppm), the activity coefficients of ketoprofen are very high (about 10000). It is well known that these semi-empirical models do not give good predictions for high activity coefficients.

So, in order to take into account the overestimation of the interaction parameters, these ketoprofen-water parameters have been re-calculated from experimental data obtained in the ternary system, at each temperature, and in the range of high $R_{\mathrm{a}}$ value $\left(R_{\mathrm{a}}>0.70\right)$. Indeed, the highest absolute deviations are obtained in this range.

Tables 12-15 report the absolute and relative deviations between calculated and experimental data, as a function of $R_{\mathrm{a}}$, after adjustment of the interactions parameters ketoprofen-water and water-ketoprofen respectively at $10.1,20.2,30.2$ and $48.9^{\circ} \mathrm{C}$. The absolute deviations are considerably reduced for high values of $R_{\mathrm{a}}$ and the agreement is quite good. The same adjusted parameters have been used to calculate the concentrations in the smallest range of $R_{\mathrm{a}}$. The results remain reasonably good, for the range of considered concentrations. For $48.9{ }^{\circ} \mathrm{C}$, only few experimental points are available

Table 15

Relative deviations between the calculated and the experimental concentrations of ketoprofen as a function of $R_{\mathrm{a}}$ at $48.9{ }^{\circ} \mathrm{C}$ (after adjustment of the interaction parameters between ketoprofen and water)

\begin{tabular}{lll}
\hline $\begin{array}{l}R_{\mathrm{a}}(\mathrm{kg} \text { acetone/ } \\
\mathrm{kg} \text { acetone water })\end{array}$ & $\begin{array}{l}\text { Absolute deviations } \\
(\mathrm{kg} \text { ketoprofen } / \mathrm{kg} \text { solution })\end{array}$ & $\begin{array}{l}\text { Relative deviations } \\
\text { on concentration }(\%)\end{array}$ \\
\hline & $\mathrm{AAD}=0.004$ & $\mathrm{ARD}=0.7$ \\
0.852 & 0.002 & 0.2 \\
0.924 & 0.006 & 1 \\
0.950 & 0.000 & 0 \\
0.967 & 0.003 & 0.5 \\
1 & 0.011 & 2 \\
\hline
\end{tabular}


Table 16

Parameters of the UNIQUAC model for the system studied, LLE

\begin{tabular}{lcc}
\hline System & $\mathbf{i}-\mathbf{j}$ & $\mathbf{u}\left(\mathrm{J} \mathrm{mol}^{-1}\right)$ \\
\hline Ketoprofen(1)- & $1-2$ & -1059.12 \\
Acetone(2) & $2-1$ & 1404.23 \\
Ketoprofen(1)- & $1-3$ & 673.18 \\
Water(3) & $3-1$ & -125.79 \\
Acetone(2)-water(3) & $2-3$ & 3744.80 \\
& $3-2$ & -866.76 \\
\hline
\end{tabular}

because this temperature is very close to the upper limit of stability of the system. So, in that case, the predicted values must to be regarded with less confidence.

\subsection{LLE evaluation method}

As LLE data on the binary mixtures of ketoprofen-acetone and ketoprofen-water mixtures, is not available, the parameters of the UNIQUAC model were evaluated from smoothing experimental LLE data at $20.2^{\circ} \mathrm{C}$. These parameters are presented in Table 16. They have also been used to calculate the LLE at the other temperatures $\left(10.1\right.$ and $30.2{ }^{\circ} \mathrm{C}$ ) by using PROPHY software (ProSim S.A., 1993).

\subsection{LLSE evaluation method}

Figs. 6-9 present predicted and experimental curves for both LLE and LSE respectively at 20.2, 10.1, 30.2 and $48.9^{\circ} \mathrm{C}$. They show that liquid-liquid equilibria slightly depend on the temperature.

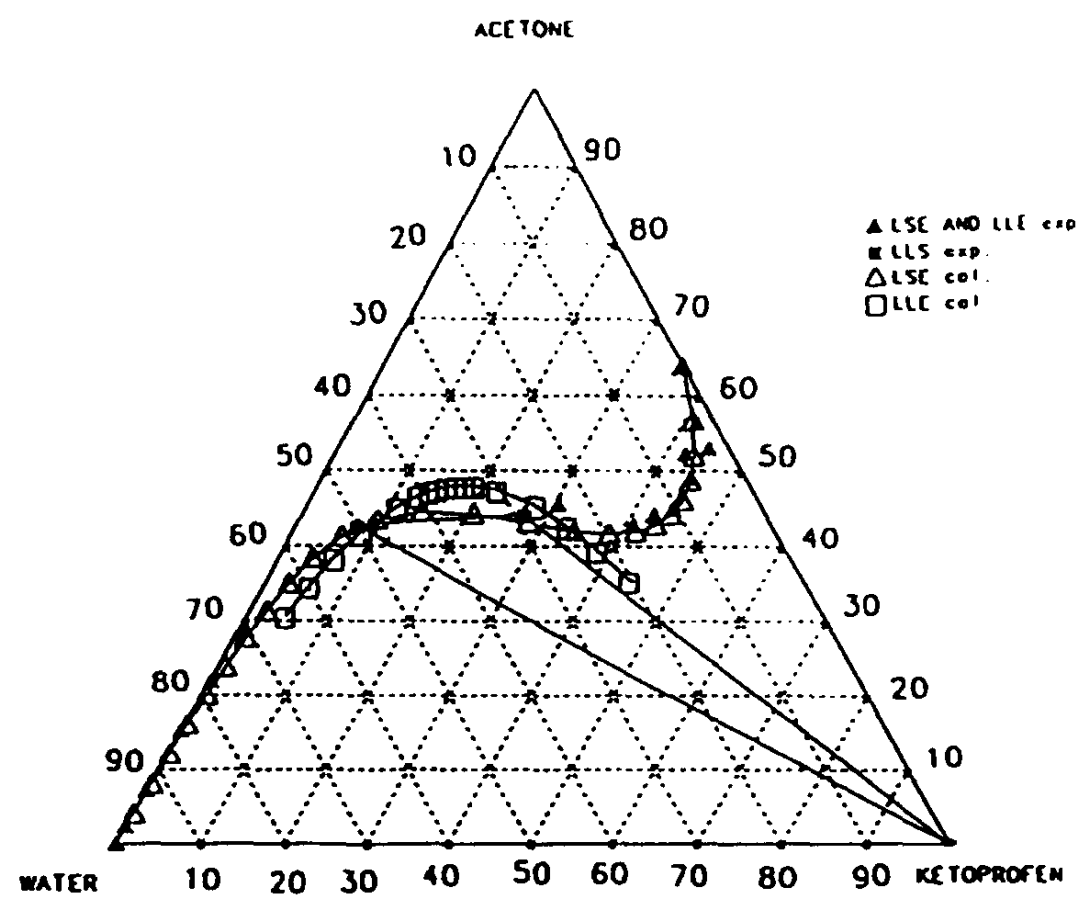

Fig. 7. Predicted LLE and LSE data (after adjustment of the interaction parameters between ketoprofen and water) and experimental data at $10.1^{\circ} \mathrm{C}$. 


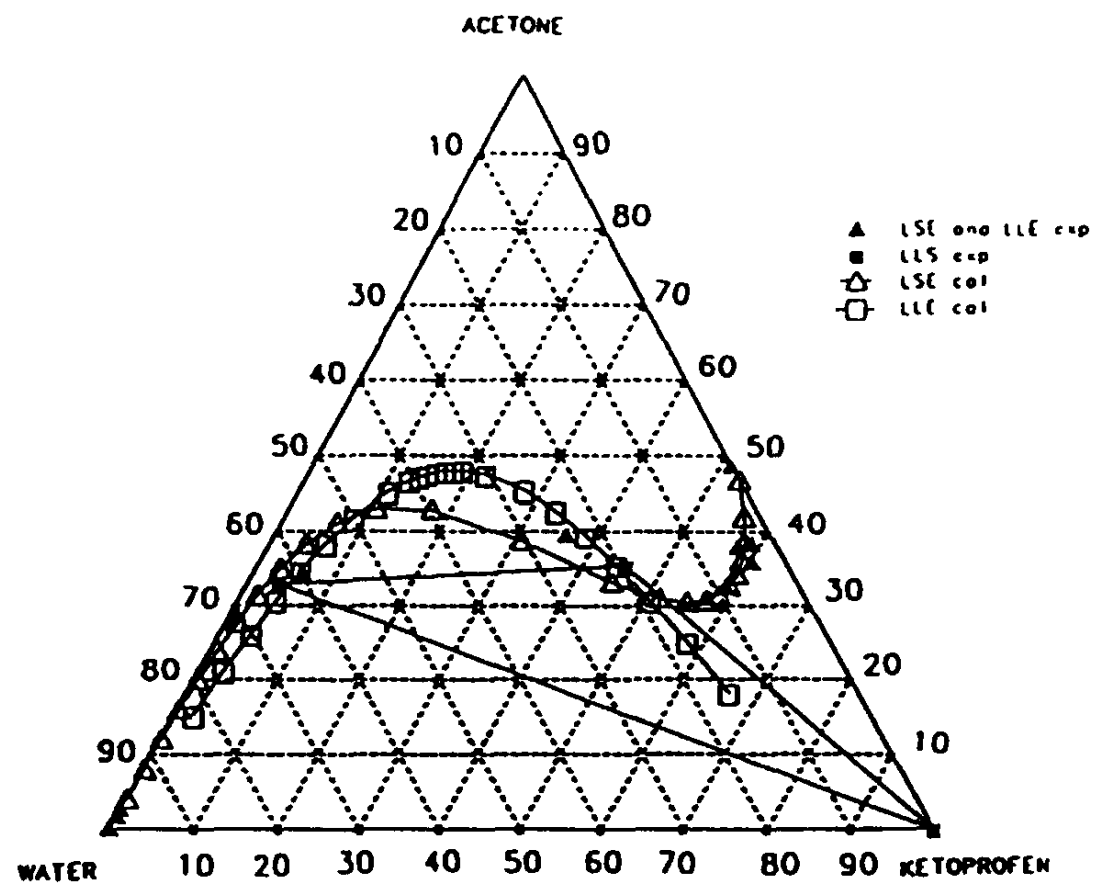

Fig. 8. Predicted LLE and LSE data (after adjustment of the interaction parameters between ketoprofen and water) and experimental data at $30.2^{\circ} \mathrm{C}$.

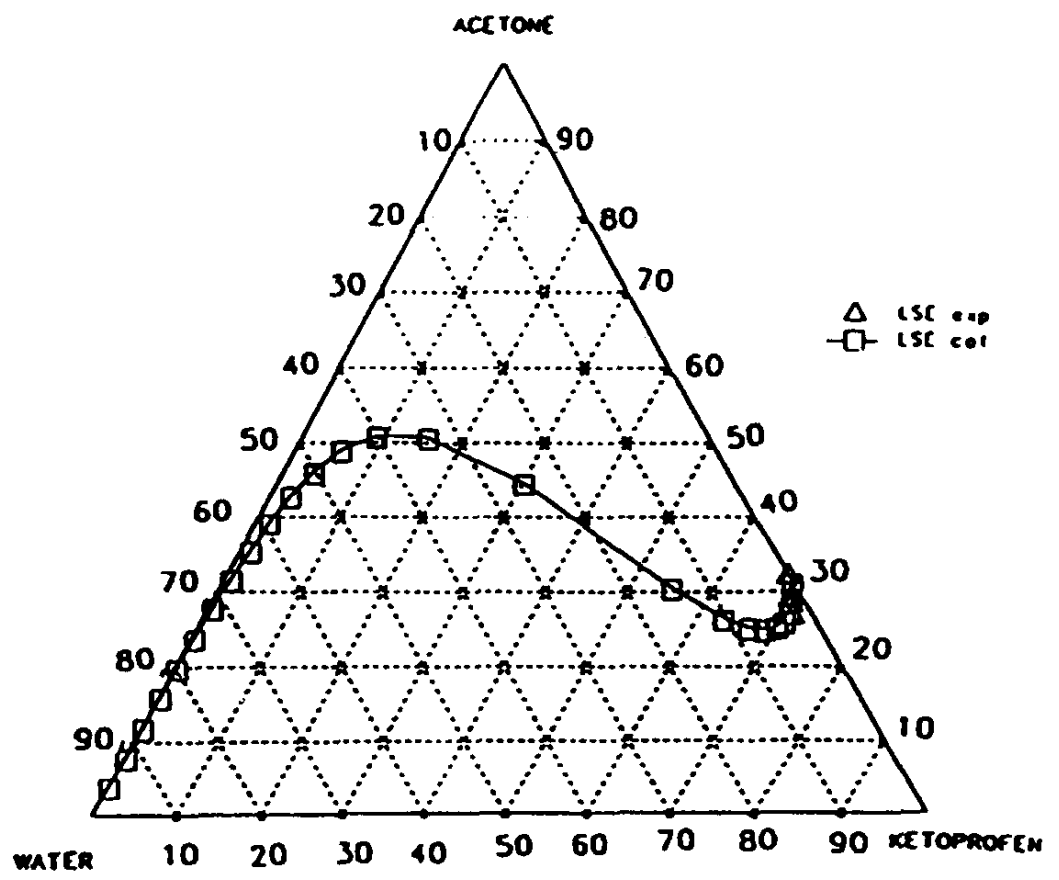

Fig. 9. Predicted and experimental data in LSE at $48.9^{\circ} \mathrm{C}$ (after adjustment of the interaction parameters between ketoprofen and water). 
The superposition of LLE and LSE predicted curves should allow us to obtain the complete ternary diagram. In the range of high $R_{\mathrm{a}}$, the intersection point, T2, between the LLE and the LSE predicted curves, is in good agreement with the experimental point. But for small $R_{\mathrm{a}}$, the intersection between LLE and LSE curves creates a point T1 that does not correspond to the experimental point. The level of agreement between the calculated and experimental intersection points ( $\mathrm{T} 1$ and $\mathrm{T} 2$ ) depends on the results of prediction of LSE previously discussed. Since T2 corresponds to the experimental point, T1 can be deduced by the following procedure: by creating the first intersection point T2 (in the Fig. 6, for example at $20.2{ }^{\circ} \mathrm{C}$ ), LLE allows to join the corresponding point T1, by the tie-line. To avoid the discontinuity between LLE and LSE at small $R_{\mathrm{a}}$ values, the tie-line has been extended up to the calculated LSE curve.

\section{Conclusion}

Experimental and calculated equilibrium data have been determined for the organic system ketoprofen-acetone-water at four temperatures $\left(10.1,20.2,30.2\right.$ and $\left.48.9{ }^{\circ} \mathrm{C}\right)$.

The experimental diagram exhibits five regions: one homogeneous, three two-phase (two liquidsolid and one liquid-liquid equilibria) and one three-phase zones. Specific experimental procedures have been applied to determine the liquid-liquid and the liquid-liquid-solid equilibria.

The behaviour of the mixtures has been explained by ketoprofen-water, ketoprofen-acetone and acetone-water interactions (hydrogen bonding).

We applied the UNIQUAC model to calculate the LSE and LLE for this system. For LSE, since the interaction parameters, ketoprofen-water and ketoprofen-acetone did not exist, they have been evaluated for each binary system from experimental data. To obtain a better agreement between experimental and calculated data, the interaction parameters ketoprofen-water have been recalculated from experimental data in the ternary system, at each temperature. After adjustment of these last parameters, the results of the semi-empirical model UNIQUAC are in agreement with experimental LSE data. For LLE, we have evaluated the missing parameters from smoothing experimental data at $20.2{ }^{\circ} \mathrm{C}$ (PROSIM). The obtained parameters have been used to calculate the LLE at the other temperatures. Finally prediction of the ternary diagram can be carried out by the presented methods.

\section{List of symbols}

$A_{\mathrm{k}} \quad$ Van der Waals surface area of group or component $\mathrm{k}\left(\mathrm{cm}^{2} / \mathrm{mol}\right)$

$\mathrm{AAD}$ average absolute deviation: $\mathrm{AAD}=\frac{\sum\left|W_{\mathrm{i}}^{\text {exp }}-W_{\mathrm{i}}^{\text {cal }}\right|}{N_{\exp }}$

ARD average relative deviation AAD $=\frac{\Sigma\left|\frac{W_{i}^{\exp }-W_{i}^{\text {cal }}}{W_{i}^{\exp }}\right| \cdot 100}{N_{\text {exp }}}(\%)$

$l_{\mathrm{i}} \quad$ pure-component constant defined in Eq. (4) $(-)$

$N_{\text {exp }} \quad$ number of experimental data (-)

$q_{\mathrm{i}} \quad$ UNIQUAC group surface parameters of pure component i (-) 
$Q_{\mathrm{k}} \quad$ group area parameter for group k (-)

$R \quad$ ideal gas constant $\left(\mathrm{J} \mathrm{mol}^{-1} \mathrm{~K}\right)$

$R_{\mathrm{k}} \quad$ group volume parameter for group k (-)

$R_{\mathrm{a}} \quad$ acetone mass ratio (kg of acetone $\mathrm{kg}^{-1}$ of acetone-water mixture)

$r_{i} \quad$ UNIQUAC group volume parameter of pure component $i(-)$

$T$ temperature $\left({ }^{\circ} \mathrm{C}\right)$

$T_{\mathrm{m}} \quad$ melting temperature of the solid (K)

$u_{\mathrm{ij}} \quad$ UNIQUAC binary interaction parameter $\left(\mathrm{J} \mathrm{mol}^{-1}\right)$

$V_{\mathrm{k}} \quad$ Van der Waals volume of group or component $\mathrm{k}\left(\mathrm{cm}^{3} \mathrm{~mol}^{-1} \times 10^{9}\right)$

$W_{\mathrm{S}}^{*} \quad$ solubility of solid, $\mathrm{S}\left(\mathrm{kg}\right.$ of $\mathrm{S} \mathrm{kg} \mathrm{kg}^{-1}$ of solution)

$x_{\mathrm{i}} \quad$ mol fraction of component $\mathrm{i}(-)$

$z \quad$ coordination number, $z=10,(-)$

\subsubsection{Greek letters}

$\Delta H_{\operatorname{mix}}$ enthalpy of mixture (cal mol ${ }^{-1}$ )

$\Delta H_{\mathrm{m}}$ enthalpy of melting $\left(\mathrm{J} \mathrm{mol}^{-1}\right)$

$\phi_{i} \quad$ molecular volume of component i (-)

$\gamma_{i} \quad$ activity coefficient of component i (-)

$\gamma_{\mathrm{i}}^{\mathrm{C}} \quad$ combinatorial contribution of activity coefficient of component i (-)

$\gamma_{i}^{R} \quad$ residual contribution activity coefficient of component i (-)

$\nu_{\mathbf{k}}^{(i)} \quad$ integer number of groups of type $\mathrm{k}$ in the molecule i (-)

$\theta_{i} \quad$ molecular surface area of component i (-)

$\tau_{\mathrm{ij}} \quad$ UNIQUAC parameter see Eq. (11) (-)

\subsubsection{Subscripts}

aq aqueous liquid phase

$i, j \quad$ components $i$ and $j$

org organic liquid phase

\subsubsection{Superscripts \\ cal calculated \\ exp experimental \\ $\mathrm{Ke} \quad$ ketoprofen \\ L liquid phase \\ S solid solute}

\section{Acknowledgements}

The authors wish to acknowledge Rhône-Poulenc-Rorer Company and the French Ministry of University Education and Research (MESR) for their financial supports to this project. 


\section{References}

Abrams, D.S. and Prausnitz, J.M., 1975. Statistical thermodynamics of liquid mixtures: A new expression for the excess Gibbs energy of partly or completely miscible systems. AIChE J., 21: 116-128.

Briard, P. and Rossi, J C., 1990. Ketoprofene. Acta Cryst. C46: 1036-1038.

Bondi, A., 1964. Van der Waals Volumes and Radii. J. Phys. Chem., 68(3): 441-451.

Bustamante, P. and Selles, E., 1983. Prediccion de la solubilidad segùn Martin: Aplicaciòn al ketoprofeno en mezclas polares. C.I.F. 2 (2. a ép.): 403-407.

Cavalier-Frontin, F.; Pèpe, G.; Verducci, J., Siri, D. and Jacquier, R.; 1992. Prediction of the best linear precursor in the synthesis of cyclotetrapeptides by molecular mechanic calculations. J. Am. Chem. Soc., 114: 8885-8890.

Franks, F. and Ives, D.J.G., 1966. The structural properties of alcohol-water mixtures. Quat. Rev., 20(1): 1-44.

Mullin, J.W., 1972, Crystallization. Butterworth, London, pp. 41-42.

ProSim S.A., 1993, Manuel technique.

Timmermans, J., 1960. The physico-chemical constants of binary systems in concentrated solutions, Interscience, New York, Vol. 4, pp. 32-47.

Walas, S. M., Phase equilibria in chemical engineering, 1985. Butterworth, Boston, pp. 397-400, 205-207. 